\title{
Hydrological responses to rainfall events including the extratropical cyclone Gloria in two contrasting Mediterranean headwaters in Spain; the perennial font del Regàs and the intermittent Fuirosos
}

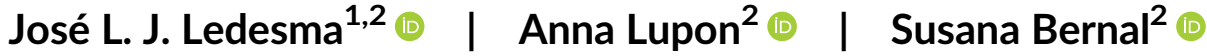

${ }^{1}$ Institute of Geography and Geoecology, Karlsruhe Institute of Technology (KIT), Karlsruhe, Germany

${ }^{2}$ Integrative Freshwater Ecology Group, Centre for Advanced Studies of Blanes, Spanish National Research Council (CEABCSIC), Blanes, Spain

\section{Correspondence}

José L. J. Ledesma, Institute of Geography and Geoecology, Karlsruhe Institute of Technology (KIT), Reinhard-Baumeister-Platz 1, 76131 Karlsruhe, Germany.

Email: jose.ledesma@kit.edu

\section{Funding information}

Agència de Gestió d'Ajuts Universitaris i de Recerca, Grant/Award Number: BP2018-00082; European Commission, Grant/ Award Number: H2020-MSCA-IF2018-834363; Ministerio de Ciencia e Innovación, Grant/Award Numbers: FJCl2017-32111, RTI2018-094521-B-100, RYC2017-22643

\begin{abstract}
Catchment hydrological responses to precipitation inputs, particularly during exceptionally large storms, are complex and variable, and our understanding of the associated runoff generation processes during those events is limited. Hydrological monitoring of climatically and hydrologically distinct catchments can help to improve this understanding by shedding light on the interplay between antecedent soil moisture conditions, hydrological connectivity, and rainfall event characteristics. This knowledge is urgently needed considering that both the frequency and magnitude of extreme precipitation events are increasing worldwide as a consequence of climate change. In autumn 2018, we installed water level sensors to monitor stream water and near-stream groundwater levels at two Mediterranean forest headwater catchments with contrasting hydrological regimes: Font del Regàs (sub-humid climate, perennial flow regime) and Fuirosos (semi-arid climate, intermittent flow regime). Both catchments are located in northeastern Spain, where the extratropical cyclone Gloria hit in January 2020 and left in ca. $65 \mathrm{~h}$ outstanding accumulated rainfalls of $424 \mathrm{~mm}$ in Font del Regàs and $230 \mathrm{~mm}$ in Fuirosos. During rainfall events of low mean intensity, hydrological responses to precipitation inputs at the semi-arid Fuirosos were more delayed and more variable than at the sub-humid Font del Regàs. We explain these divergences by differences in antecedent soil moisture conditions and associated differences in catchment hydrological connectivity between the two catchments, which in this case are likely driven by differences in local climate rather than by differences in local topography. In contrast, during events of moderate and high mean rainfall intensities, including the storm Gloria, precipitation inputs and hydrological responses correlated similarly in the two catchments. We explain this convergence by rapid development of hydrological connectivity independently of antecedent soil moisture conditions. The data set presented here is unique and contributes to our mechanistic understanding on how streams respond to rainfall events and exceptionally large storms in catchments with contrasting flow regimes.
\end{abstract}




\section{KEYWORDS}

antecedent soil moisture conditions, catchment hydrological connectivity, climate extreme, environmental monitoring, extreme hydrological event, heavy rainfall, Mediterranean climate, rainfall intensity

\section{1 | INTRODUCTION}

Investigating the variability in hydrological responses to precipitation inputs across climatic settings can shed light on many of the unsolved questions in catchment hydrology (Blöschl et al., 2019). For example, our understanding of the impacts of extreme precipitation events on catchment hydrology and associated solute export is still limited, despite their known adverse consequences for ecological and socioeconomic systems (Kunkel et al., 1999; Llasat et al., 2010). On one hand, predicting the occurrence of extreme precipitation events is still highly uncertain due to their limited spatial coherence (Alexander et al., 2006; Hartmann et al., 2013), even after recent improvements in the quality and resolution of satellite and meteorological station data used in climatic models (Hartmann et al., 2013; Morbidelli et al., 2020). On the other hand, hydrological responses associated with this type of events are complex and diverse (Kaushal et al., 2018; McMillan et al., 2018). Thus, uncertainty persists regarding timing, duration, intensity, frequency, and spatial extent of precipitation events, particularly extreme rainfall events (Rojas et al., 2011), and regarding the associated catchment hydrological responses. Resolving how catchments respond under extraordinary circumstances is urgently needed considering that the frequency and magnitude of extreme precipitation events have increased globally in recent years and are likely to further increase in coming decades as a consequence of climate change (Hartmann et al., 2013; Huntington, 2006).

At the regional scale, hydrological responses to precipitation inputs and extreme events can be highly variable. In natural, unregulated systems, this variability is usually attributed to a combination of factors. Among these factors, local climate and topography stand out as the most important ones because they in turn control antecedent soil moisture conditions and hydrological connectivity (Barker et al., 2016; Bracken et al., 2013; Marchi et al., 2010; McMillan et al., 2018). Accordingly, climatic and topographic features ultimately determine the predominant hydrological regime within a catchment, and also its resulting hydrological resilience, that is, its ability to buffer the impact of external forcings such as extreme precipitation events (Botter et al., 2013). It has been proposed that persistent flow regimes, characteristic of perennial streams with extensive catchment hydrological connectivity, usually show higher sensitivity and lower stability to climate anomalies than erratic flow regimes, typical of intermittent streams with low-mean discharges and low-catchment hydrological connectivity (Botter et al., 2013). Therefore, streams with contrasting flow regimes might exhibit different hydrological responses and sensitivity to rainfall events, including extreme precipitation events. Rainfall event characteristics play an important and complex role in this context. For example, mean rainfall intensity rather than rainfall amount has been proposed to drive the development of hydrological connectivity through non-linear responses, especially in intermittent streams located in arid and semiarid areas (Azarnivand et al., 2020; Gomi et al., 2008).

The western Mediterranean region is characterized by a broad range of local climates and topography that favours the occurrence of locally intense rainfall episodes and results in catchments with differentiated flow regimes. Consequently, this region offers high potential to investigate catchment hydrological responses under contrasting flow regimes and during extreme precipitation events. Indeed, extreme events are more frequent in the western than in the eastern Mediterranean region and the rest of Europe (Llasat et al., 2010; Marchi et al., 2010). For example, as many as 4.6 flood events per year were recorded in eastern Spain (located in the western Mediterranean) between 1990 and 2006, whereas only 0.7 flood events per year were recorded in Greece (located in the eastern Mediterranean; Llasat et al., 2010). Long-term records (>100 years) indicate that extreme precipitation events in the western Mediterranean region occur mostly in autumn and winter, and can be accompanied by dramatic increases in water levels and flooding of extensive areas (Llasat et al., 2010; Toreti et al., 2010). However, despite the associated ecological and socioeconomic impacts of these episodes, appropriate observational hydrological data is still lacking, and most of the available information is based on post-event reconstruction analyses (Gaume et al., 2009; Marchi et al., 2010). The establishment of longterm environmental monitoring programmes that incorporate the use of high-frequency in situ sensors can help to improve our mechanistic understanding of the effects of such extreme events on catchment hydrology, not only in this region, but also in other sites worldwide (Kaushal et al., 2018).

Here, we present a hydrological monitoring effort recently established at two Mediterranean forest headwater catchments located in northeastern Spain (i.e., in the western Mediterranean region): Font del Regàs and Fuirosos. The two catchments show contrasting hydrological regimes (perennial vs. intermittent) linked to their contrasting local climates (sub-humid vs. semi-arid). Thus, they offer the possibility to investigate hydrological responses to precipitation inputs under contrasting flow and climatic conditions. Monitoring of hydrological variables, namely stream water and near-stream groundwater levels, started in September 2018. The period since then has been exceptionally wet, including several large rainfall events. Of particular interest was the 'extratropical cyclone' Gloria that hit eastern Spain in January 2020. The storm Gloria approached the Iberian Peninsula from the open Atlantic Ocean, and it stalled in the western Mediterranean Sea for several days until it slowly drifted southwest, passed over the Strait of Gibraltar and dissipated (Martín-Vide, 2020). In its wake, Gloria carried extraordinarily high and persistent winds and rainfalls, causing large floods and widespread environmental and 
economic damage (Amores et al., 2020). This extreme precipitation event brought, during a period of ca. $65 \mathrm{~h}$, outstanding accumulated rainfalls of $424 \mathrm{~mm}$ in Font del Regàs and $230 \mathrm{~mm}$ in Fuirosos. In this study, we present the hydrological data that we reconstructed from this massive storm, together with the hydrological data from the monitoring activity from September 2018 until March 2020.

Our main objective was to investigate overall differences in hydrological responses to precipitation inputs between these two contrasting headwater catchments, and relate these differences to rainfall event characteristics. We expected larger variability and less responsiveness to precipitation inputs in the intermittent stream, which is characterized by a marked seasonality in stream discharge and hydrological connectivity compared with the perennial stream. We also aimed to examine specific differences in hydrological responses between the two catchments during the storm Gloria, and highlight the uniqueness of this data set by putting this extreme precipitation event into a broader climatic context. These aims are important because they can contribute to advance our understanding of the processes controlling catchment hydrological responses to precipitation inputs, including extreme events, across climatic settings.

\section{2 | MONITORING SITES}

The two monitoring sites are headwaters of the $865 \mathrm{~km}^{2}$ Tordera catchment, which flows into the western part of the Mediterranean Sea in northeastern Spain (Figure 1). The pronounced altitude gradient in the Tordera catchment, ranging from 0 to $1706 \mathrm{~m}$ above sea level (a.s.l.), results in a mosaic of orographic features and microclimates with contrasting local temperature, precipitation, and evapotranspiration regimes. This climatic gradient translates into a mosaic of hydrological regimes that includes perennial, intermittent, and ephemeral headwater tributaries. These characteristics make the Tordera catchment an exceptional field laboratory to study hydrological responses under contrasting conditions within the same geographical region. Our two monitoring catchments, Font del Regàs and Fuirosos, are similar in size and represent two endmembers of such contrasting conditions despite being separated by only ca. $15 \mathrm{~km}$. The two sites are located in separate mountains and thus have distinctively different precipitation patterns: Font del Regàs is located in the Montseny massif, whereas Fuirosos is located in the Montnegre i el Corredor range (Figure 1). Anthropogenic activity at

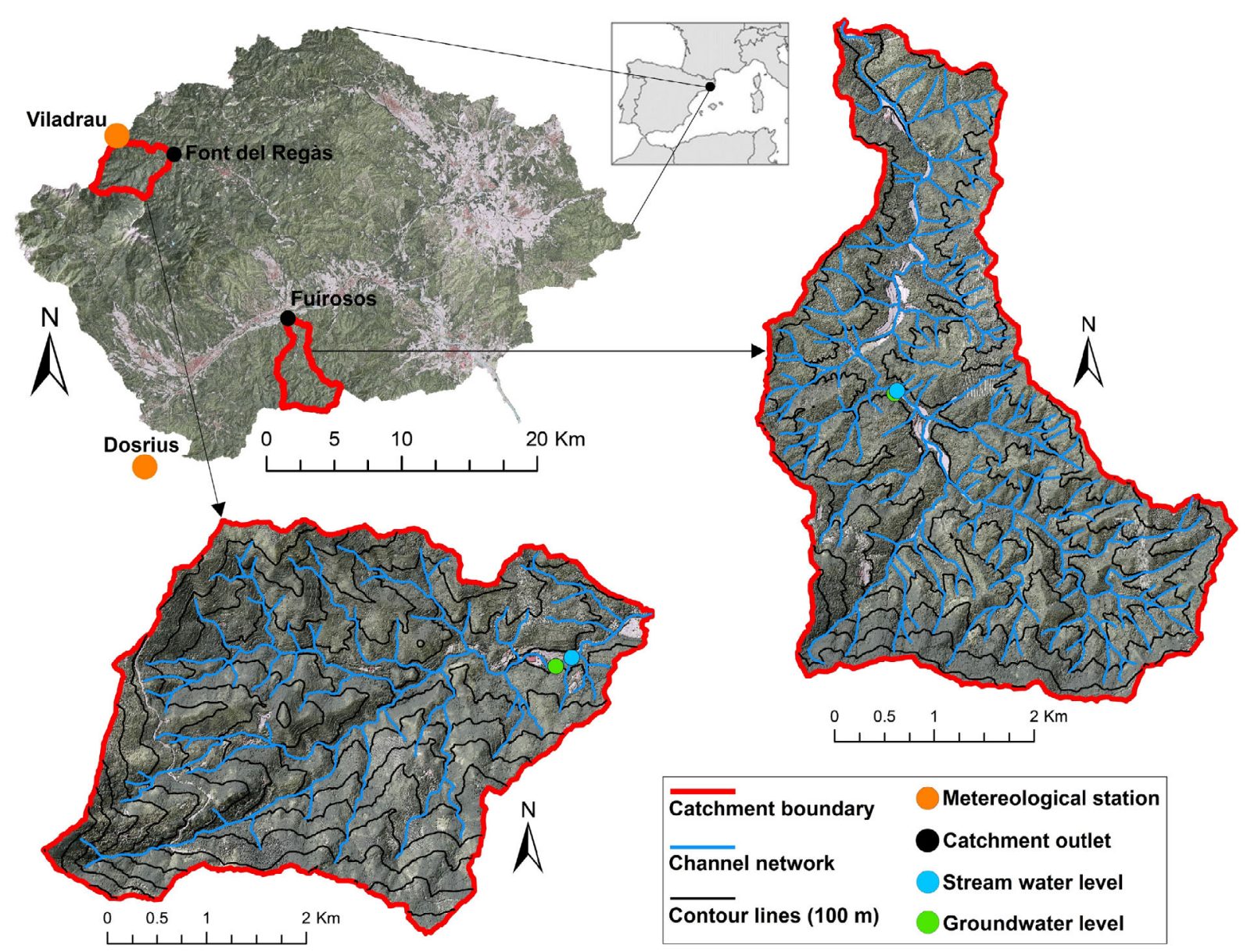

FIGURE 1 Location of the Tordera catchment within Spain and relative position of the two monitoring headwater catchments Font del Regàs (perennial stream) and Fuirosos (intermittent stream), as well as of the meteorological stations Viladrau (953 m a.s.l.) and Dosrius (460 $\mathrm{m}$ a.s.l.) used in this study. The locations of the monitoring sensors for stream water and near-stream groundwater levels within each catchment are also shown 
both sites is low, given their location in natural protected forest areas.

The Font del Regàs catchment, located in the Montseny Natural Park (outlet at $41^{\circ} 50^{\prime} \mathrm{N}, 2^{\circ} 28^{\prime} \mathrm{E}$ ), includes a total drainage area of $15.5 \mathrm{~km}^{2}$ that ranges between 405 and $1603 \mathrm{~m}$ a.s.l. (Figure 1). The local climate is sub-humid Mediterranean with mild winters, wet springs, and dry summers. Long-term (1940-2000) average annual air temperature was $12.1 \pm 2.5^{\circ} \mathrm{C}$ (average $\pm \mathrm{SD}$ ), whereas average annual precipitation during this period was $925 \pm 151 \mathrm{~mm} \mathrm{year}^{-1}$ (Lupon, Bernal, et al., 2016). A vegetation gradient follows the altitude gradient in the catchment. Deciduous European beech (Fagus sylvatica L.) forest and a small proportion of heathlands (Calluna vulgaris L. and gramineae) dominate the upper, steeper parts of the catchment (800 to $1600 \mathrm{~m}$ a.s.I.), whereas evergreen oak (Quercus ilex) forest dominates in the lower half of the catchment (400 to $1000 \mathrm{~m}$ a.s.l.). A well-developed (10-20 m wide) riparian forest, composed of a mixture of tree species including black alder (Alnus glutinosa L.), black locust (Robinia pseudoacacia L.), European ash (Fraxinus excelsior L.), and black poplar (Populus nigra L.), is found in near-stream zones in the lower, U-shaped part of the valley (500-750 m a.s.l.; Lupon, Bernal, et al., 2016; Poblador et al., 2017). No riparian vegetation exists in the upper, $\mathrm{V}$-shaped part of the catchment. Annual potential evapotranspiration rates depend on the forest type and correspond to 550-650 mm year ${ }^{-1}$ in the evergreen forest, 600-750 mm year ${ }^{-1}$ in the deciduous forest, and $750-1000 \mathrm{~mm}$ year $^{-1}$ in the riparian forest (Àvila et al., 1996; Llorens \& Domingo, 2007; Lupon et al., 2018). The overall potential evapotranspiration in the catchment as estimated with the Penman-Monteith equation is ca. 750 to $800 \mathrm{~mm}_{\text {year }}{ }^{-1}$ (Lupon et al., 2018). Upslope soils are sandy, with a 3-5 cm-deep O horizon followed by a 5-20-cm deep A horizon and a $>100 \mathrm{~cm}$-deep $B$ horizon. Groundwater in the upslopes flows more than $1 \mathrm{~m}$ below the soil surface (b.s.s.) and percolates rapidly through the soil towards the stream by preferential flow paths (Àvila et al., 1995). The catchment is drained by a perennial stream that exhibits a persistent flow regime (sensu Botter et al., 2013). The geomorphology of the streambed changes along the stream; at the upper parts of the catchment the streambed is composed by rocks and cobbles and wetted width is ca. $1.5 \mathrm{~m}$, whereas sands and gravels predominate at the valley bottom, where wetted width is ca. $3.5 \mathrm{~m}$. Monitoring of hydrological data at Font del Regàs, including stream discharge and groundwater levels, was previously limited to a few years in the early 2010s (see e.g., Lupon et al., 2018; Lupon, Bernal, et al., 2016).

The Fuirosos catchment, located in the Montnegre-Corredor Natural Park (outlet at $41^{\circ} 43^{\prime} \mathrm{N}, 2^{\circ} 34^{\prime} \mathrm{E}$ ), includes a total drainage area of $16.5 \mathrm{~km}^{2}$ that ranges between 80 and $758 \mathrm{~m}$ a.s.l. (Figure 1). The seasonality of temperature and precipitation at Fuirosos is similar to that of Font del Regàs, but the overall climate is warmer and drier, typically semi-arid Mediterranean due to the high evapotranspiration in relation to the precipitation (Medici et al., 2008). During the period 2009-2019, average annual air temperature was $13.9 \pm 0.5^{\circ} \mathrm{C}$ and average annual precipitation was $658 \pm 216 \mathrm{~mm}$ year $^{-1}$, as measured by a nearby meteorological station. Catchment forests are dominated by evergreen species, including cork oak (Quercus suber L.), Aleppo pine (Pinus halepensis L.), and maritime pine (Pinus pinaster L.). Small proportions of deciduous forests are present in the upper parts of the catchment and include chestnut (Castanea sativa L.), hazel (Corylus avellana L.), and downy oak (Quercus pubescens L.). Lower parts of the stream channel are embedded in sandy alluvial deposits and flanked by a well-developed riparian zone, which is $10-20 \mathrm{~m}$ wide and consists mainly of plane tree (Platanus hispanica L.) and black alder (Bernal et al., 2005). Annual potential evapotranspiration for the overall catchment ranges between 975 and $1418 \mathrm{~mm}$ year $^{-1}$, as estimated with the Penman-Monteith equation for different periods between 1999 and 2006 (Bernal et al., 2012; Medici et al., 2008). Upslope soils are poorly developed, with a thin organic $O$ horizon, or more frequently an Ao horizon that transition into a $B$ horizon at ca. $5 \mathrm{~cm}$ depth. Groundwater in the upslopes flows more than $2 \mathrm{~m}$ b.s.s. and percolates rapidly through the soil towards the stream by preferential flow paths (Butturini et al., 2003). The catchment is drained by an intermittent stream that exhibits an erratic flow regime (sensu Botter et al., 2013). No surface runoff is observed during the driest months of the year, typically from late June to late September (Bernal et al., 2002). The streambed is dominated by sand, rocks, and boulders and mean wetted width increases along the stream from 1.5 to $2.5 \mathrm{~m}$ during the months with observable surface runoff. Stream discharge and groundwater levels were previously monitored during the late 1990s and the 2000s (see Vázquez et al., 2013 and within references).

\section{3 | MATERIAL AND METHODS}

\section{1 | Field installations and available data}

In September 2018, we established a parallel monitoring programme for hydrological data collection at both Font del Regàs and Fuirosos. We used a series of water level data logger sensors ( $\mathrm{HOBO}{ }^{\circledR}$ U20-001-04) to record high-frequency stream water and nearstream groundwater levels at both catchments. All sensors were set to record measurements at 10-min resolution. In this study, data until 3 March 2020 are presented. The impossibility to access either of the sites during and a few days after the storm Gloria (20-23 January 2020) prevented measurements of stream discharge during the extreme flow conditions associated with this event. We built rating curves for both Font del Regàs and Fuirosos, but only with observations made during relatively low stream discharge conditions. Hence, these rating curves did not provide estimates of stream discharge with acceptable limits of uncertainty for this study and we based our analyses on raw stream water level measurements, from which, in any case, stream discharge values are ultimately derived. Therefore, we argue that hydrological response evaluations can be made in terms of water levels without the need to invoke discharge data as both the measurement (i.e., water level) and the derived product (discharge) would be positively related (e.g., stream peak discharge and the highest stream water level during an event will always coincide). 
Stream water levels at Font del Regàs were measured near the outlet, at a location draining an area of $14.2 \mathrm{~km}^{2}$, from September 2018 to November 2019. The sensor used to record water levels was attached to a concrete block and placed on the middle part of the riverbed. However, reliable data were only available from September 2018 to September 2019, including periods of data loss between December 2018 and April 2019 (Table 1). Because of drastic changes in riverbed sediment, in November 2019 we moved the monitoring of stream levels to a different location $900 \mathrm{~m}$ upstream, draining an area of $13.0 \mathrm{~km}^{2}$. Unfortunately, data from this new location were lost because the storm Gloria damaged the installation and sensor, which was attached to a small manmade wall built on one side of the stream channel. An additional sensor was installed in a $1.2 \mathrm{~m}$-deep monitoring well placed $2 \mathrm{~m}$ from the stream channel in the riparian zone nearby the first stream location. Groundwater levels were recorded here from September 2018 to March 2020, except for a period of data loss in February 2019 and a period in which the sensor was stolen between mid-December 2019 and early January 2020.

At Fuirosos, stream water levels were measured at a location draining the upper $9.9 \mathrm{~km}^{2}$ of the catchment by a sensor attached to a concrete block and placed on the middle part of the riverbed. Except for a few gaps, data were recorded from October 2018 to January 2020 , when the sensor was scoured by the storm Gloria and precluded a full time series until March 2020 (Table 1). Groundwater levels were recorded in a $1.2 \mathrm{~m}$-deep monitoring well located close to the stream channel in the riparian area adjacent to the stream sensor location, from October 2019 to March 2020. Groundwater levels measured at both catchments will be referred to as "near-stream groundwater levels' hereafter.

For this study, we used precipitation and temperature time series from two meteorological stations managed by the Servei Meteorològic de Catalunya (SMC, Catalan Meteorological Service), which is the most important institution managing meteorological stations regionally, uses state of the art equipment and technology, has exhaustive quality controls, and thus produces high quality data. Precipitation is measured by tipping buckets and temperature by thermocouple sensors. We considered Viladrau station, located in the Montseny massif, ca. $4 \mathrm{~km}$ northwest the outlet of Font del Regàs, and only a few hundred meters from the northern end of the catchment, as the best source of meteorological data representing this site. For Fuirosos, we considered the data from Dosrius station as the best source of meteorological data. Dosrius is located in the Montnegre i el Corredor range, ca. $13 \mathrm{~km}$ southwest our stream water level monitoring station in Fuirosos (Figure 1). Both Viladrau (953 m a.s.l.) and Dosrius (460 m a. s.l.) are located at intermediate elevations with respect to Font del Regàs and Fuirosos catchments, respectively. In both cases, the available data goes back to the beginning of 2009 and consisted of 1-hour (January 2009-April 2014) and 30-min (April 2014-March 2020) resolution accumulated precipitation (SMC, 2020).

In this study, both the magnitude and, more notably, the timing of the precipitation were important to pursue our objectives. We assessed the uncertainty in both the timing and the magnitude of the precipitation estimates from Viladrau and Dosrius stations by taking into account additional precipitation data from other nearby SMC stations and from other local sources (Supporting Information, Figure S1, Table S1, Figure S2, Table S2). In order to assess uncertainty in precipitation timing, we compared the starting time of the rainfall events identified for Viladrau and Dosrius within the study period (September 2018-March 2020) with the starting time of the corresponding events for the nearby stations considered in each case. Similarly, in order to assess uncertainty in precipitation magnitude, we compared the total accumulated precipitation at Viladrau and Dosrius with that of the corresponding nearby stations, for the study period or for periods with overlapping data. These analyses showed that, for both catchments, the uncertainty in precipitation timing is negligible (<30 min) and the uncertainty in precipitation magnitude is low ( $<10 \%$; see Supporting Information for full details). Therefore, we are confident that the data from both Viladrau and Dosrius stations represent well the timing and magnitude of the precipitation falling in Font del Regàs and Fuirosos, respectively.

\subsection{Data treatment and statistical analyses}

Precipitation data was used to identify rainfall events at each monitoring catchment for the study period (September 2018-March 2020). For this assessment, we considered that rainfall events (i) consisted of a minimum accumulated precipitation of $5 \mathrm{~mm}$ and (ii) were separated

TABLE 1 Available 10-min resolution hydrological data from the two monitoring headwater catchments Font del Regàs (perennial stream) and Fuirosos (intermittent stream) presented in the study. The percentages of missing dates within the available data periods are also shown. The extratropical cyclone Gloria took place on the period 20-23 January 2020. The date format is dd/mm/yyyy in all cases

\begin{tabular}{llll} 
Catchment & Hydrological data & Available data periods & Missing dates (\%) \\
\hline Font del Regàs & Stream water level & $17 / 09 / 2018$ to $27 / 12 / 2018 ;$ \\
& & $29 / 01 / 2019$ to $13 / 02 / 2019 ;$ \\
& & $17 / 04 / 2019$ to $21 / 09 / 2019$ \\
\hline Font del Regàs & Near-stream groundwater level & $17 / 09 / 2018$ to $13 / 02 / 2019 ;$ \\
& & $06 / 03 / 2019$ to $16 / 12 / 2019 ;$ \\
\hline Fuirosos & Stream water level & $13 / 01 / 2020$ to $03 / 03 / 2020$ \\
& & $11 / 10 / 2018$ to $13 / 02 / 2019 ;$ \\
\hline Fuirosos & & $06 / 03 / 2019$ to $19 / 03 / 2019 ;$ \\
\hline
\end{tabular}


from each other for periods without precipitation of at least $24 \mathrm{~h}$. We chose this threshold for defining a rainfall event because hydrological responses to precipitation inputs below $5 \mathrm{~mm}$ are generally undetectable in Mediterranean catchments (Gallart et al., 2002). In addition, the conservative 24-hour inter-event period selected followed Azarnivand et al. (2020) and Ledesma et al. (2021) and aimed to ensure that the hydrological responses studied in connection with the rainfall events did not overlap between events.

We compared (i) accumulated precipitation (mm), (ii) total event duration (h), (iii) mean rainfall intensity (as the accumulated precipitation divided by the event duration, $\mathrm{mm} \mathrm{h}^{-1}$ ), and (iv) maximum 30-min rainfall intensity (determined by the resolution of the meteorological station data and expressed in $\mathrm{mm} \mathrm{h}^{-1}$ ) of the rainfall events from Font del Regàs (sample size, $N=46)$ and Fuirosos $(N=41)$ using Wilcoxon rank-sum tests. The Wilcoxon rank-sum test is a non-parametric test (i.e., no assumptions are made about how the data are distributed) used to determine whether two groups of samples come from the same population (same percentiles), or differ only in location (central value or median; Helsel \& Hirsch, 2002). In other words, the method tests whether one group tends to produce larger observations than the second group. With this analysis we examined whether there were differences in rainfall event characteristics between the two catchments during the study period. For each rainfall event descriptor, we also performed a paired Wilcoxon signed-rank test to further assess differences in rainfall characteristics between events occurring simultaneously at the two catchments (i.e., starting within $24 \mathrm{~h}$ of each other, $N=31$ ). The paired Wilcoxon signed-rank is similar to the Wilcoxon rank-sum test but applied to two groups of samples with paired observations and is used to determine whether the median difference between paired observations equals zero or not (Helsel \& Hirsch, 2002). Mean and maximum 30-min rainfall intensities were further classified according to the Spanish State Meteorological Agency definitions into 'light' $\left(\leq 2 \mathrm{~mm} \mathrm{~h}^{-1}\right)$, 'moderate' (2$15 \mathrm{~mm} \mathrm{~h}^{-1}$ ), 'heavy' (15-30 $\mathrm{mm} \mathrm{h}^{-1}$ ), 'very heavy' $\left(30-60 \mathrm{~mm} \mathrm{~h}^{-1}\right.$ ), or 'torrential' ( $\geq 60 \mathrm{~mm} \mathrm{~h}^{-1}$; Llasat, 2001).

The four hydrological time series that were recorded at 10-min intervals (i.e., stream water and near-stream groundwater levels at both Font del Regàs and Fuirosos; Table 1) were integrated into 30-min resolutions in order to be compared with the corresponding precipitation time series through cross-correlation (Brockwell \& Davis, 1991). Cross-correlation is used to evaluate the statistical correlation between two data time series at different lag times and thereby to explore the lag time in the synchronicity between an explanatory time series (e.g., precipitation) and a response time series (e.g., water levels; Lee et al., 2006; Padilla \& Pulido-Bosch, 1995). Here, cross-correlation was used to explore the lag times of stream water and near-stream groundwater levels that maximized the correlation with precipitation inputs at Font del Regàs and Fuirosos for each identified rainfall event. The analysis was done for all instances when complete data series were available (e.g., no cross-correlation was possible at Fuirosos during the summer dry period) and extended from the beginning of the corresponding rainfall event to $8 \mathrm{~h}$ after the end of the event. This 8-hour margin was included in order to ensure that the potential lag time in the hydrological response with respect to the precipitation input was covered. Varying the 8-hour margin by $\pm 4 \mathrm{~h}$ led to similar results (not shown). Cross-correlations were computed using the ccf function in R version 3.6.3 (R Core Team, 2012).

In addition, for each identified rainfall event, we further characterized the associated hydrological response for the available data by inspection of the stage hydrographs. Specifically, we considered that the beginning of the hydrological response coincided with the time when either stream water or near-stream groundwater levels increased at least $0.4 \mathrm{~cm}$ between two consecutive hydrological records (i.e., between a 30-min interval) following the beginning of the associated rainfall event. In turn, the end of each hydrological response was defined as the time when stream water or near-stream groundwater levels decreased less than $0.1 \mathrm{~cm}$ over four consecutive records (i.e., a 2-hour period). For each hydrological response identified, we also recorded the time of the stage hydrograph peak.

Using Wilcoxon rank-sum tests, we examined differences in the hydrological response to rainfall events between Font del Regàs and Fuirosos by comparing: (i) the lag time of the hydrological response that maximized the correlation with precipitation inputs, (ii) the time lapse between the beginning of a rainfall event and the beginning of the associated hydrological response, (iii) the time to reach the stage hydrograph peak from the beginning of the hydrological response, and (iv) the total duration of the hydrological response. Additionally, we aimed to test whether the average lag time of the hydrological response that maximized the correlation with precipitation inputs differed between the two catchments. To do so, we performed a Tukey's honestly significant difference (HSD) test, which compares pairs of means between different groups of samples (Quinn \& Keough, 2002). The test is suitable for groups that have unequal sample sizes and can be used when distributions are normal or approximately normal, as it was the case here. These analyses were done separately for stream water and near-stream groundwater data. Moreover, we used Wilcoxon rank-sum tests to assess whether hydrological responses described by the four descriptors differed between stream water and near-stream groundwater levels for each individual catchment.

Finally, we investigated relationships between rainfall event characteristics and hydrological responses in each catchment by using linear, segmented linear, and non-linear regression models between the four rainfall event descriptors (accumulated precipitation, total duration, mean rainfall intensity, and maximum 30-min rainfall intensity) and the lag time of the hydrological response that maximized the correlation with precipitation inputs. These analyses were done by combining stream water and near-stream groundwater data in each catchment. The significance level for all statistical analyses was set at $p<0.05$.

\section{4 | RESULTS}

\section{1 | Precipitation inputs and hydrological responses during the monitoring period}

During the study period, the total precipitation at Font del Regàs and Fuirosos was 1923 and $1365 \mathrm{~mm}$, respectively, equivalent to 1277 
and $906 \mathrm{~mm}$ year $^{-1}$. These values are well above the long-term annual averages at both catchments, although the study period only covered one spring-summer season and two autumn-winter seasons, which are generally wetter (Figure $2 a, b$ ). Both stream water and nearstream groundwater levels responded to precipitation inputs, except for a particularly long period of no observable surface runoff at the intermittent Fuirosos that lasted almost 4 months, from the 30 June to 23 October 2019 (Figure 2c-f).

Accumulated precipitation, total event duration, mean rainfall intensity, and maximum 30-min rainfall intensity were not statistically different between the rainfall events identified at Font del Regàs and Fuirosos (Figure 3, Table S3, Table S4). All descriptors showed a wide range of values, which were similar between the two catchments. Medians (interquartile ranges, IQR) were: 15 (6.6$35)$ and 19 (7.5-34) $\mathrm{mm}$ for accumulated precipitation, 8.0 (4.0-26) and $9.0(3.0-23) \mathrm{h}$ for rainfall event duration, 1.9 (1.0-3.2) and 2.2 (1.3-3.5) $\mathrm{mm} \mathrm{h}^{-1}$ for mean rainfall event intensity, and 8.2 (4.0-15)
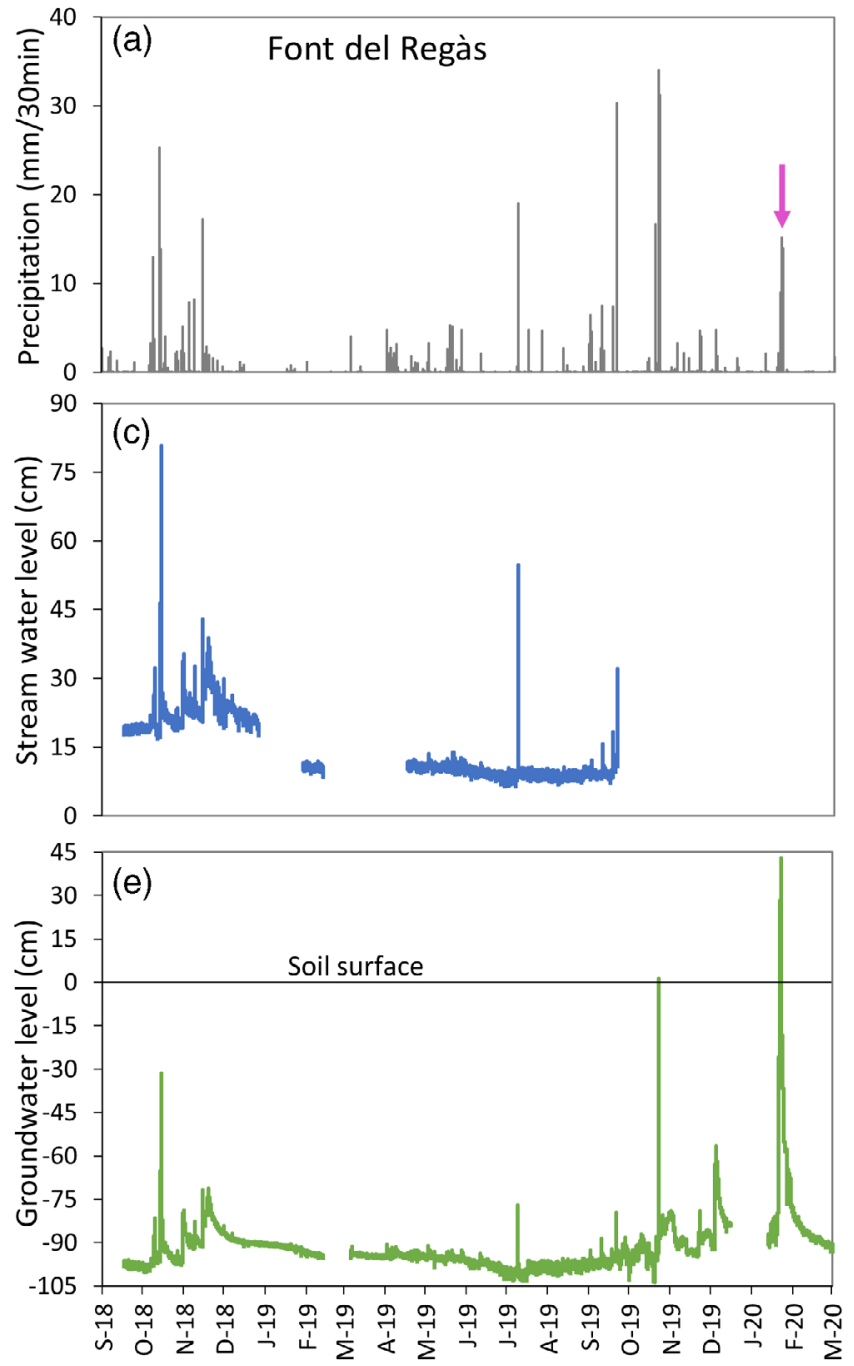

and 11 (5.3-17) $\mathrm{mm} \mathrm{h}^{-1}$ for maximum 30-min rainfall event intensity at Font del Regàs and Fuirosos, respectively. Over $20 \%$ of the rainfall events were longer than $24 \mathrm{~h}$ in both catchments and only one event in each case had a mean rainfall intensity classified as 'heavy'. The rest of the events were either 'light' (57\% in Font del Regàs and $46 \%$ in Fuirosos) or 'moderate' (41\% in Font del Regàs and $51 \%$ in Fuirosos) according to their mean rainfall intensity. Nevertheless, maximum 30-min rainfall intensities were 'heavy' and 'very heavy' in eight events at Font del Regàs (18\% of the total) and 15 events at Fuirosos ( $37 \%$ of the total). In addition, two 'torrential' maximum 30-min rainfall intensities were recorded at Font del Regàs. When the comparison between catchments was repeated for the paired rainfall events $(N=31)$, accumulated precipitation at Font del Regàs was statistically higher than at Fuirosos (mean difference $=21.5 \mathrm{~mm}, p=0.002$, Figure S3). None of the other three rainfall event descriptors was statistically different between the two sites for the paired comparison (Figure S3).
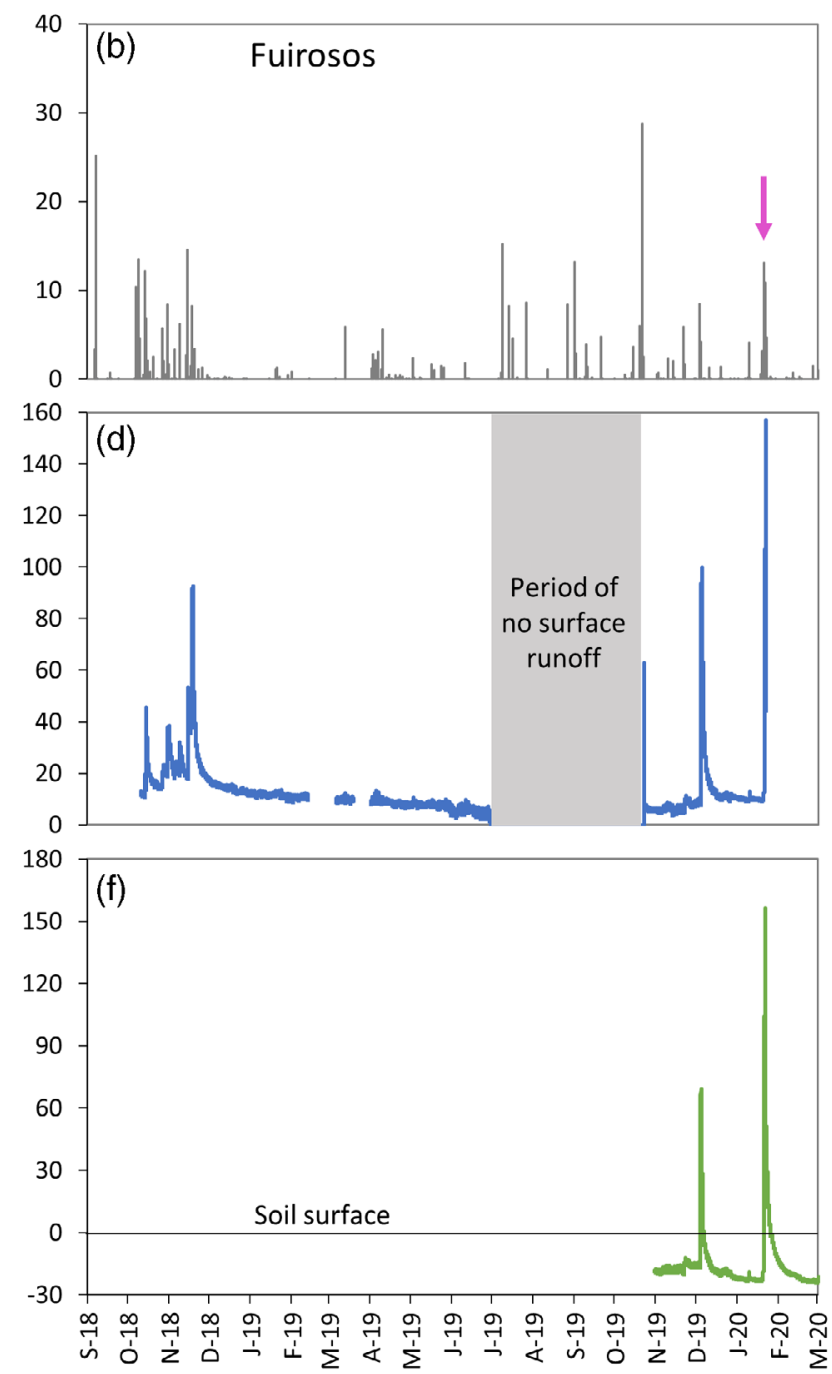

FIGURE 2 Time series of (a, b) precipitation and (c, d) available 10-min resolution stream water level, and (e, f) near-stream groundwater level during the study period for the two monitoring headwater catchments Font del Regàs (perennial stream, left-side panels) and Fuirosos (intermittent stream, right-side panels). Pink arrows indicate the time when the extratropical cyclone Gloria took place (20-23 January 2020) 

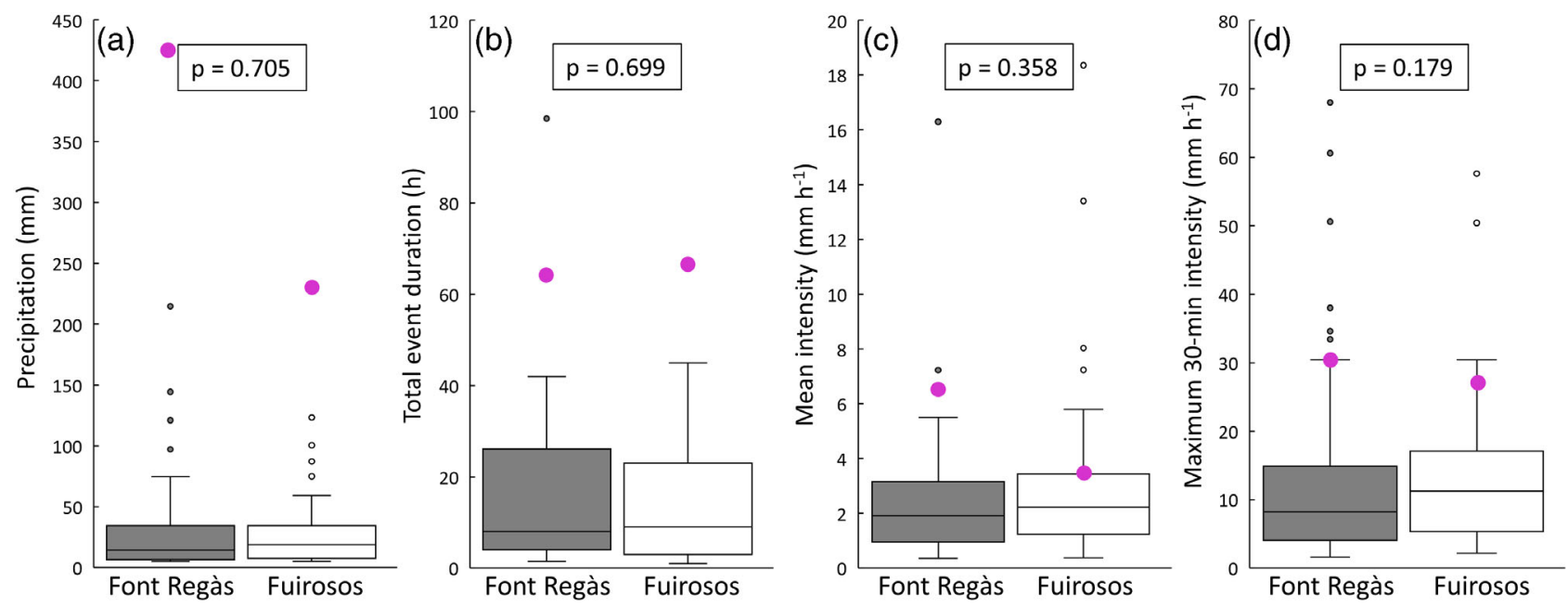

FIGURE 3 Characterization of rainfall events $(\geq 5 \mathrm{~mm}$ ) at the two headwater catchments font del Regàs (perennial stream, $N=46)$ and Fuirosos (intermittent stream, $N=41$ ) identified between September 2018 and March 2020 using distributions of (a) accumulated precipitation, (b) total event duration, (c) mean rainfall intensity, and (d) maximum 30-min rainfall intensity. On each box, the central mark indicates the median, and the bottom and top edges of the box indicate the $25 \%$ and $75 \%$, respectively. The whiskers extend to the most extreme data points not considered outliers, which are data points exceeding a distance of 1.5 times the interquartile range below the $25 \%$ or above the $75 \%$. $p$-values corresponding to Wilcoxon rank-sum tests are shown in each case. The pink dots represent the corresponding values for the extratropical cyclone Gloria (20-23 January 2020)

Stream water and near-stream groundwater level responses to precipitation inputs showed a wide range of values, especially at Fuirosos (Figure 4). The lag time of the stream water level response that maximized the correlation with precipitation inputs was significantly longer and more variable (wider IQR) at Fuirosos, that is, 8.5 (5.9-12.1) $\mathrm{h}(\mathrm{N}=26)$ than at Font del Regàs, that is, $4.8(4.0-6.0) \mathrm{h}$ ( $N=26$; Wilcoxon test, $p<0.001$; Figure 4a). A similar pattern was observed for the near-stream groundwater level data, where median lag times were $9.0(5.0-13.1) \mathrm{h}(\mathrm{N}=6)$ at Fuirosos and $5.0(4.5-7.0) \mathrm{h}$ $(N=43)$ at Font del Regàs, although in this case the difference was not statistically significant because of the small sample size of the near-stream groundwater level data at Fuirosos (Wilcoxon test, $p=0.075)$. Average ( \pm SD) values of lag times were significantly higher at Fuirosos than at Font del Regàs for both stream water $(9.7 \pm 5.5$ vs. $5.9 \pm 4.0 \mathrm{~h}$; Tukey HSD, $p=0.007$ ) and near-stream groundwater (9.6 $\pm 5.6 \mathrm{~h}$ versus $6.1 \pm 3.3 \mathrm{~h}$; Tukey HSD, $p=0.031$ ) levels.

The time lapse between the beginning of a rainfall event and the beginning of the associated hydrological response was not statistically different between the two catchments (Wilcoxon tests, $p=0.39$ for stream water level data, $p=0.84$ for near-stream groundwater level data; Figure 4b). However, the time lapse for the stream water level was perceptibly longer (larger median) and more variable at Fuirosos, that is, $5.0(2.5-7.5) \mathrm{h}(\mathrm{N}=19)$, than at Font del Regàs, that is, 3.5 (3.0-6.0) h ( $N=23)$. A similar pattern was observed for the nearstream groundwater level data, where median time lapse was 4.0 (2.0-6.2) h (N=5) at Fuirosos and $3.5(3.0-5.5) \mathrm{h}(\mathrm{N}=35)$ at Font del Regàs. On the other hand, the time to reach the stage hydrograph peak was significantly longer and more variable at Fuirosos, that is, $11(5.5-28) \mathrm{h}(\mathrm{N}=19)$, than at Font del Regàs, that is, $5.5(3.5-8.5) \mathrm{h}$ $(N=23)$, for the stream water level data (Wilcoxon test, $p=0.040$;
Figure 4c). For the near-stream groundwater level data, the time to reach stage hydrograph peak was not statistically different between the two catchments (Wilcoxon test, $p=0.62$ ), but Fuirosos showed again a longer median and more variability, that is, $11(3.5-25) \mathrm{h}$ $(N=5)$, than Font del Regàs, that is, $5.5(3.5-12.5) \mathrm{h}(N=35)$. Finally, the total duration of the hydrological response was not statistically different between Font del Regàs and Fuirosos (Wilcoxon tests, $p=0.44$ for stream water level data, $p=0.74$ for near-stream groundwater level data), but Fuirosos showed higher variability for both the stream water, that is, $23(12-68) \mathrm{h}(N=18)$ versus 22 (11$35)$ h $(N=22)$, and near-stream groundwater data, that is, 20 (12399) h $(N=5)$ versus $24(14-39)$ h $(N=35)$, than Font del Regàs, respectively (Figure $4 d$ ).

There were no statistical differences between stream water and near-stream groundwater within each individual catchment for any of the four hydrological response descriptors (Wilcoxon tests, $p>0.25$ in all cases). Indeed, stream water and near-stream groundwater levels showed similar dynamics and the associated hydrological response descriptors were highly linearly correlated between the two compartments $\left(R^{2}>0.9\right.$ in all cases except for lag times in Font del Regàs, where the correlation was $\mathrm{R}^{2}=0.6$; Figure S4).

Lower mean rainfall event intensities at Fuirosos led to a broad range of lag times, whereas higher mean rainfall event intensities led to more restricted and generally shorter lag times. This behaviour was best captured by a two-segment negative linear regression with a tipping point at $1.6 \mathrm{~mm} \mathrm{~h}^{-1}$ for the combined stream water and nearstream groundwater data from Fuirosos (Figure 5a). We reanalysed this segmented linear relationship for five subsets of events by randomly removing ca. $20 \%$ of the data (i.e., 7 out of 32 observations) in each subset and found that the relationship held, with statistically 

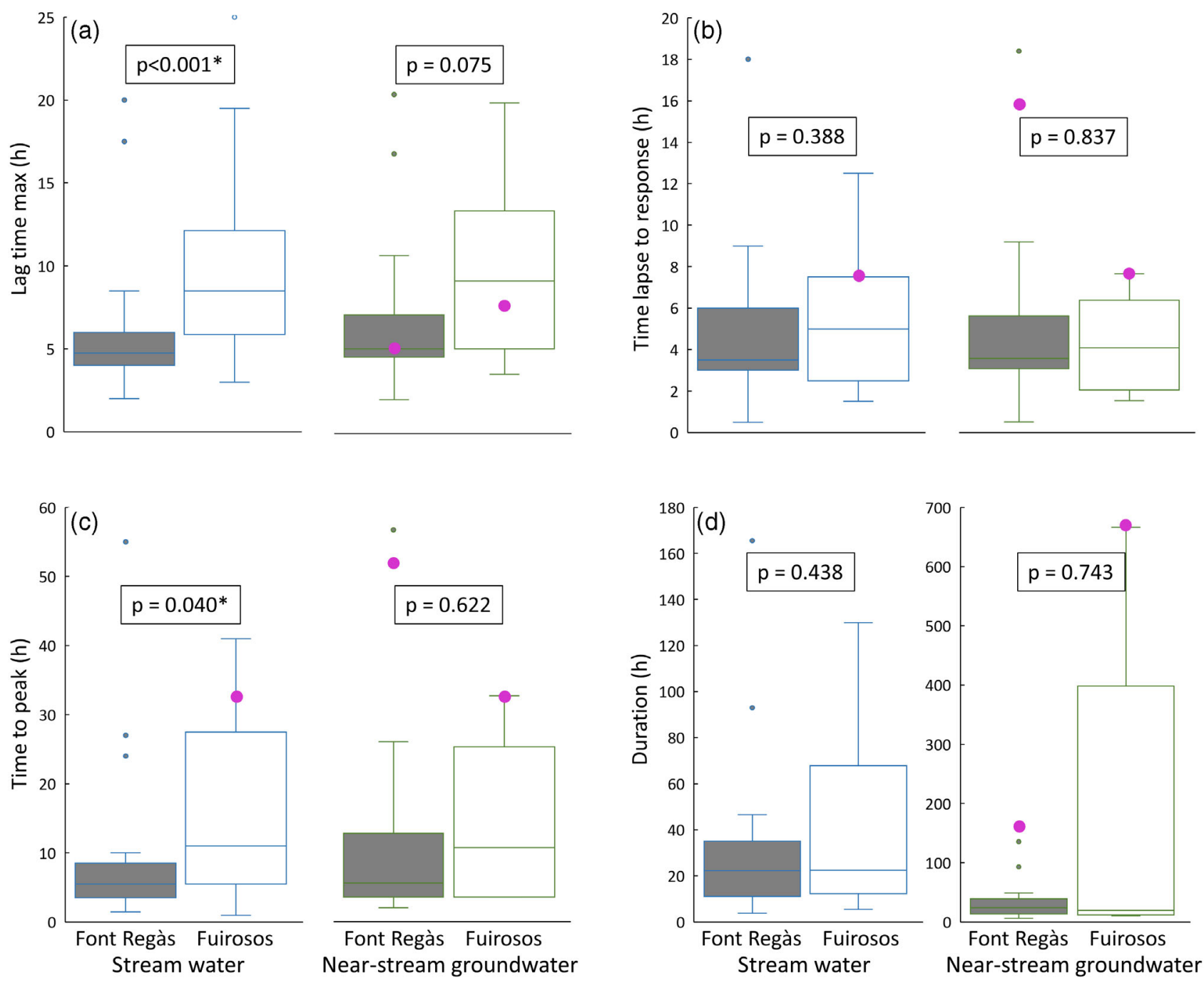

FIGURE 4 Characterization of stream water and near-stream groundwater responses during rainfall events at the two headwater catchments font del Regàs (perennial stream) and Fuirosos (intermittent stream) during the period September 2018-March 2020 using distributions of (a) lag times of the hydrological response that maximized the correlation with precipitation inputs according to cross-correlation $(N=26,26,43,6)$, (b) time lapse between the beginning of a rainfall event and the beginning of the associated hydrological response $(N=23,19,35,5)$, (c) times to reach the stage hydrograph peak from the beginning of the hydrological response $(N=23,19,35,5)$, and (d) the total duration of the hydrological response $(N=22,18,35,5)$. On each box, the central mark indicates the median, and the bottom and top edges of the box indicate the $25 \%$ and $75 \%$, respectively. The whiskers extend to the most extreme data points not considered outliers, which are data points exceeding a distance of 1.5 times the interquartile range below the $25 \%$ or above the $75 \%$. Note the different scale in the $y$-axis for the two plots in panel (d). $p$-values corresponding to Wilcoxon rank-sum tests are shown in each case. The pink dots represent, when available, the corresponding values for the extratropical cyclone Gloria (20-23 January 2020)

significant tipping points varying between 1.6 and $1.9 \mathrm{~mm} \mathrm{~h}^{-1}$ (Table S5). This pattern was not observed for the Font del Regàs data and no other relevant linear, segmented linear, or non-linear relationships between rainfall event characteristics and lag times were found for any of the catchments (not shown). Further, the average lag time associated with mean rainfall event intensities lower than $1.6 \mathrm{~mm} \mathrm{~h}^{-1}$ at Fuirosos was significantly longer than that associated with mean rainfall event intensities higher than $1.6 \mathrm{~mm} \mathrm{~h}^{-1}$, as well as longer than the average lag time from the Font del Regàs catchment irrespective of mean rainfall intensity (Tukey HSD, $p<0.01$; Figure $5 b$ ). To make the case stronger, we repeated the comparison using a threshold of $1.9 \mathrm{~mm} \mathrm{~h}^{-1}$ (instead of $1.6 \mathrm{~mm} \mathrm{~h}^{-1}$ ) and obtained the same result (not shown).

\section{2 | Precipitation inputs and hydrological responses during the extratropical cyclone Gloria}

During the single storm event Gloria, Font del Regàs received $424 \mathrm{~mm}$ of precipitation in $64.5 \mathrm{~h}$, which is nearly half of the long-term average annual precipitation in the catchment and by far the largest rainfall event during the study period (Figure 3a). The accumulated 

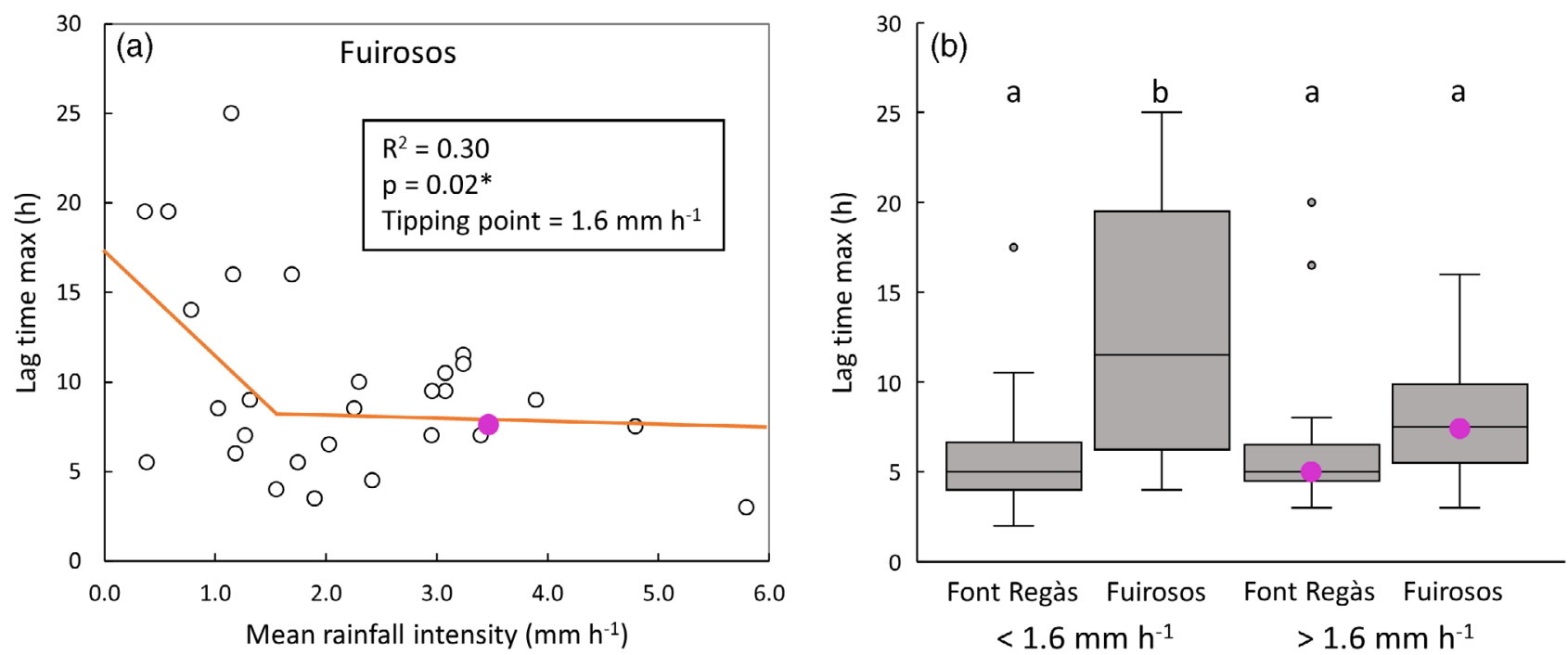

FIG URE 5 (a) Two-segment linear regression between mean rainfall event intensity and lag times of the hydrological response that maximized the correlation with precipitation inputs according to cross-correlation (lag time max) for the combined stream water and near-stream groundwater data from Fuirosos (intermittent stream). (b) Distributions of 'Lag time max' associated with mean rainfall event intensities lower and higher than $1.6 \mathrm{~mm} \mathrm{~h}^{-1}$ at the two monitoring headwater catchments font del Regàs (perennial stream) and Fuirosos (intermittent stream) $(N=30,12,39,20)$. On each box, the central mark indicates the median, and the bottom and top edges of the box indicate the $25 \%$ and $75 \%$, respectively. The whiskers extend to the most extreme data points not considered outliers, which are data points exceeding a distance of 1.5 times the interquartile range below the $25 \%$ or above the $75 \%$. Connecting letters corresponding to a Tukey's HSD test are also shown. The pink dots represent, when available, the corresponding values for the extratropical cyclone Gloria (20-23 January 2020)

precipitation during the storm in Fuirosos was lower $(230 \mathrm{~mm}$ in $66.5 \mathrm{~h}$ ), but also amounted more than one third of the total precipitation in a regular year and was also the largest during the study period. The storm Gloria was the second longest of all recorded events during the study period at Font del Regàs and the longest at Fuirosos (Figure 3b). Yet, the mean rainfall intensity of the event was 'moderate' in both cases and comparable with other events during the study period (Figure 3c). In its turn, maximum 30-min rainfall intensity was 'very heavy' at Font del Regàs and 'heavy' at Fuirosos, also comparable with other recorded events in this period (Figure 3d). Over a longer record, from January 2009 to December 2019, only another three-day event in March 2013 accumulated a total rainfall amount comparable with Gloria at Font del Regàs $(357 \mathrm{~mm}$, or $84 \%$ of the amount accumulated during Gloria). The other four largest rainfall events on record at this site showed values that were about half of that registered during Gloria, that is, between 191 and $215 \mathrm{~mm}$ (Table S6). At Fuirosos, the five events showing the largest accumulated rainfall amounts during the same 11-year period were small compared to that registered during Gloria, varying between 117 and $153 \mathrm{~mm}$ (Table S7).

The near-stream groundwater levels at both Font del Regàs and Fuirosos followed the pattern of precipitation during Gloria, which consisted of three apparent subevents that led to three peaks in the stage hydrograph in each case (Figure 6a,b). Notably, the last of the subevents at Fuirosos was low in magnitude compared to that of Font del Regàs. After the storm, near-stream groundwater levels at Fuirosos decreased over a longer period than at Font del Regàs. The near-stream groundwater level at Font del Regàs was above the soil surface for 1.5 days, reaching a maximum water height of $43 \mathrm{~cm}$ over the soil surface in the morning of the 23 January 2020 (Figure 2e, Figure 6a). At Fuirosos, the near-stream groundwater level was above the soil surface for 5.5 days, reaching a maximum height of $157 \mathrm{~cm}$ over the soil surface in the morning of the 22 January 2020 (Figure 2f, Figure 6b). According to the cross-correlation analysis, the lag time that maximized the correlation between precipitation inputs and near-stream groundwater levels during Gloria was slightly longer at Fuirosos (7.5 h) than at Font del Regàs ( 5 h; Figure $6 c, d)$. The value for Fuirosos was lower than the median value estimated for all events during the study period, whereas the value for Font del Regàs corresponded to the median of the study period at this site (Figure 4a). The time lapse between the beginning of Gloria and the beginning of the associated near-stream groundwater level response and the time to reach the stage hydrograph peak were long compared to other recorded events at both sites (Figure $4 b, c$ ). The total duration of the response was the longest of all events at both sites (Figure $4 d$ ).

\section{DISCUSSION}

The monitoring strategy implemented at the two study sites, including both stream water and near-stream groundwater levels, allowed us to assess the variability in stream responses to precipitation inputs at two contrasting Mediterranean headwater catchments. We found that stream responses at the intermittent Fuirosos were more delayed and more variable than at the perennial Font del Regàs, especially during rainfall events of low intensity. In contrast, during intense rainfall 

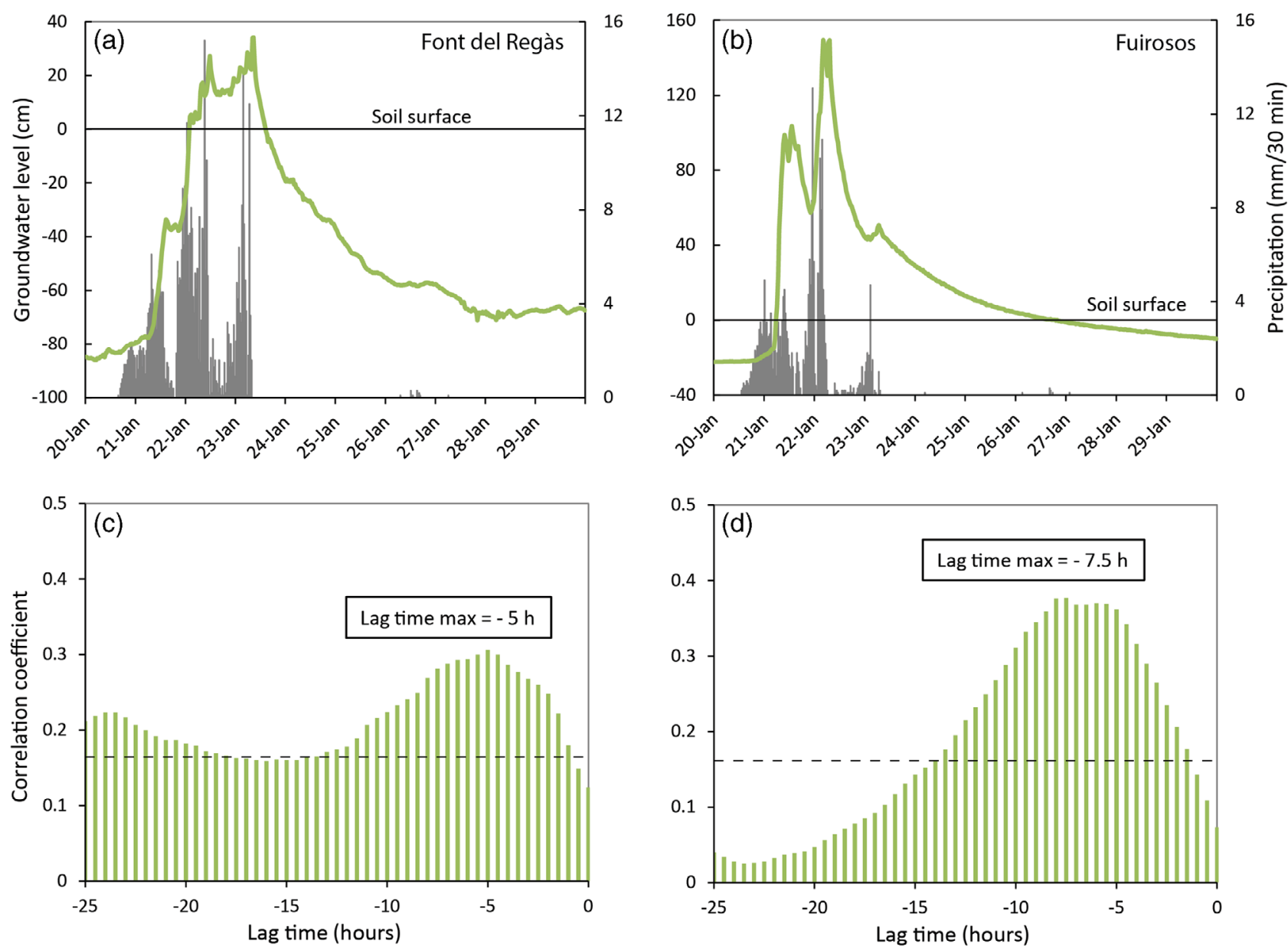

FIGURE 6 Time series of 30-min resolution precipitation and near-stream groundwater levels during and 7 days after the 3-day extratropical cyclone Gloria event for the two headwater catchments (a) Font del Regàs (perennial stream) and (b) Fuirosos (intermittent stream). (c) and (d) show the cross-correlation between 30-min precipitation and 30-min near-stream groundwater levels for the 3-day Gloria event for the lag time frame of $25 \mathrm{~h}$ for Font del Regàs and Fuirosos, respectively. The lag time with the highest correlation coefficient (Lag time max) is indicated in each case. Negative lag time values correspond to preceding times of precipitation inputs in relation to hydrological responses. Positive values correspond to the inverse and thus are not relevant in this case (not shown). Correlation values above the dashed line were statistically significant $(p<0.05)$

events such as the extratropical cyclone Gloria, stream responses at the two catchments were similar. Here, we discuss the potential drivers of the observed variability between the two catchments, as well as the exceptionality of the storm Gloria within the climatic context of this Mediterranean region.

\section{1 | Variability in stream responses at Font del Regàs (perennial) and Fuirosos (intermittent)}

The implementation of a parallel high-frequency hydrological monitoring programme at the Mediterranean headwaters Font del Regàs (perennial) and Fuirosos (intermittent) and the comparative analyses presented here revealed that responses to rainfall events at the semiarid catchment were slower and more variable than at the sub-humid catchment. This pattern was clear for both stream water and nearstream groundwater across the four hydrological response descriptors investigated (Figure 4). We are confident that these results are robust because the uncertainty in the timing of the precipitation at the two selected meteorological stations representing the two catchments was lower than the resolution of the data (i.e., $30 \mathrm{~min}$; Supporting Information, Figure S1, Table S1, Figure S2, Table S2). The observed differences in stream responses between the two catchments could be the result of differences in rainfall event characteristics, catchment properties (such as soil moisture conditions and hydrological connectivity), or a combination of both.

We found that the duration, mean rainfall intensity, and maximum 30-min rainfall intensity of the rainfall events were similar between the two catchments during the study period (Figure 3). Therefore, a priori, rainfall event characteristics do not appear to be good candidates in explaining the overall delay and variability in stream responses at Fuirosos compared to Font del Regàs. Yet, we found that mean rainfall event intensity influenced the lag times at Fuirosos, which were longer and more variable compared to the rest of the 
Fuirosos data and to Font del Regàs when mean rainfall intensities were lower than $1.6 \mathrm{~mm} \mathrm{~h}^{-1}$ (Figure 5). This threshold is close to that established by the Spanish State Meteorological Agency delimiting 'light' and 'moderate' rainfall event intensities (i.e., $2 \mathrm{~mm} \mathrm{~h}^{-1}$ ) and could be indicative of a tipping point for fundamental changes in stream responses to precipitation inputs, at least in semi-arid catchments such as Fuirosos.

We propose that, during rainfall events of light intensity, differences in soil moisture conditions preceding the events can explain the delayed responses observed at the intermittent, semi-arid Fuirosos compared with the perennial, sub-humid Font del Regàs. Antecedent soil moisture conditions can strongly influence hydrological responses within single catchments and along large drainage networks by controlling groundwater tables and hydrological connectivity and, thus, the transfer of water from catchments to streams (Àvila et al., 1992; Zimmer \& McGlynn, 2018). In our sites, riparian soil moisture averages 40 to $50 \%$ at Font del Regàs, whereas it rarely exceeds $20 \%$ at Fuirosos (Butturini et al., 2002; Lupon, Sabater, et al., 2016). Moreover, riparian groundwater levels at Font del Regàs remain relatively stable throughout the year, indicating that a permanent saturated aquifer is connected even during summer (Lupon, Bernal, et al., 2016). In contrast, riparian groundwater levels at Fuirosos experience large seasonal fluctuations and can drop down in the summer and remain disconnected from the stream for months (Butturini et al., 2003). Similar to other semi-arid catchments, previous modelling exercises identified two main groundwater storages at Fuirosos; (i) a perched, riparian shallow aquifer that has the potential to transfer water to the stream during the non-dry season, and (ii) a permanent, saturated deep aquifer located well below the streambed that is generally disconnected from the shallow aquifer and from the stream (Medici et al., 2008). These two groundwater storages are connected only during the wettest conditions.

Accordingly, consistently drier conditions in semi-arid catchments such as Fuirosos imply that a larger proportion of the catchment area is hydrologically disconnected from the stream prior to rainfall events. As a consequence, in this type of catchments, the spatial extent of hydrologically connected areas (i.e., source areas from which stream water originates) during the stream response to rainfall events of light intensity likely increase gradually and during a longer period compared to more humid catchments such as Font del Regàs, where the preevent spatial extension of hydrologically connected areas is larger and stream responses can be independent of event size (Bracken et al., 2013). Canopy interception can also contribute to limit the development of hydrological connectivity in arid and semi-arid catchments during rainfall events of low intensity (Pilgrim et al., 1988). Conversely, during events of higher mean rainfall intensities, stream responses at Fuirosos became more similar to those observed at Font del Regàs, likely because of a relatively more rapid development of hydrological connectivity across the catchment. These results are in line with previous observations and conceptualizations elaborated across geographical areas that propose that hydrological connectivity to streams increases with the intensity of precipitation inputs, especially in arid catchments with generally low connectivity (Azarnivand et al., 2020;Bracken et al., 2013; McMillan et al., 2018). This effect can be explained by 'fill and spill' mechanisms (Tromp-van Meerveld \& McDonnell, 2006), which can apply to semi-arid catchments with perched aquifers such as Fuirosos and which, as we showed here, are associated with non-linear threshold type relationships between rainfall intensity and hydrological responses (Bracken et al., 2013; McMillan et al., 2018).

Ultimately, differences in antecedent soil moisture conditions and associated hydrological connectivity at Fuirosos and Font del Regàs could be explained by differences in either local climate or topography, or a combination of both. Topographical characteristics do explain differences in soil moisture patterns and hydrological connectivity in some cases (Ali \& Roy, 2010; Jencso et al., 2009; Musolff et al., 2015; Zuecco et al., 2019). Yet, they cannot be invoked here because main topographical variables including slope $(7.5 \pm 2.5 \%$ vs. $7.2 \pm 2.5 \%$ ) and topographic wetness index ( $4.5 \pm 1.6$ vs. $4.2 \pm 1.7)$ are similar in the two catchments (Font del Regàs vs. Fuirosos, respectively). On the other hand, differences in rainfall event characteristics between the two catchments were significant in terms of precipitation amount when rainfall events were paired, and showed that precipitation was 39\% lower at Fuirosos than at Font del Regàs. This difference is credible given the low estimated uncertainty in precipitation magnitude (i.e., within 10\%) and not surprising given that the local climate at Fuirosos is reportedly drier and warmer than at Font del Regàs (e.g., $34 \%$ lower precipitation and $2.7^{\circ} \mathrm{C}$ higher temperature was reported at Fuirosos compared to Font del Regàs for the period 2009 to 2019). These differences translate into differentiated evapotranspiration rates (ca. $750 \mathrm{~mm}$ year $^{-1}$ at Font del Regàs and > $975 \mathrm{~mm}$ year $^{-1}$ at Fuirosos; Bernal et al., 2012; Lupon et al., 2018; Medici et al., 2008), eventually leading to higher water losses at Fuirosos. Consequently, local climate is in this case the primary factor driving differences in antecedent soil moisture conditions, hydrological connectivity, and stream responses, and defining the characteristic perennial versus intermittent hydrological regimes of the two study streams.

The flow regime at Fuirosos consistently includes a full season without surface runoff and a characteristic non-linear hydrological behaviour during the transitions between wet and dry conditions (Medici et al., 2008). These hydrological features further contribute to explain the overall delayed responses at Fuirosos compared to Font del Regás, as well as the wider range of hydrological responses observed in the semi-arid catchment (Figure 4). The observed large variability in hydrological responses at Fuirosos is supported by previous studies in the catchment showing large variability in runoff coefficients during rainfall events (Bernal \& Sabater, 2008), and fits into the 'erratic hydrological regime' categorization proposed by Botter et al. (2013). In contrast, the more regular pattern observed for Font del Regàs fits into the contrasting 'persistent flow regime' categorization (Bernal et al., 2019). Botter et al. (2013) suggested that erratic regimes are more resilient and thus less sensitive to, for example, climate-induced changes than persistent regimes. Our results support this idea by showing slower and more variable hydrological responses at the intermittent than at the perennial stream. However, this 
conceptualization does not imply that transitions from perennial to intermittent hydrological regimes expected from climate change and other anthropogenic alterations are desirable, because they involve a number of negative physical, biological, and socioeconomic impacts (Magand et al., 2020). It simply implies that naturally-occurring intermittent streams might have more intrinsic ability to buffer extreme precipitation events and other climate and anthropogenic-related changes than naturally-occurring perennial streams. This hypothesis will need to be further examined by future research.

\section{2 | Climatic and hydrological characterization of the extratropical cyclone Gloria}

Catastrophic and destructive floods in the western Mediterranean region are usually linked with moderately intense rainfall events of long duration (Doswell et al., 1998). These features adequately fit the characteristics of Gloria and the general pattern of decreasing mean rainfall intensity with increasing duration of rainfall event observed in the historical records of the region (Llasat, 2001). Yet, such large amounts of rainfall during a single precipitation event had not been reported before in Font del Regás and Fuirosos (Bernal et al., 2019; Butturini et al., 2002), and had not even been predicted for the future under synthetic climate scenarios (Ledesma et al., 2021). For instance, the most extreme precipitation events recorded at the two sites during the preceding 11-year period only accumulated individually about $40-80 \%$ of the rainfall amounts recorded during Gloria, further indicating that this was not a common event. In a broader spatial context, the accumulated rainfall in Fuirosos is comparable with other extreme events recorded in recent decades in the Mediterranean region, but the $424 \mathrm{~mm}$ of accumulated rainfall in Font del Regàs (with a 24-hour maximum of $209 \mathrm{~mm}$ between 21 January 2020 at 19:30 and 22 January 2020 at 19:00) are only comparable with 100-year return period daily rainfall amounts (Doswell et al., 1998; Gaume et al., 2009; Llasat et al., 2010). In this sense, the storm Gloria was extreme within the extreme precipitation events in a region where extreme episodes are relatively common (Llasat et al., 2010), highlighting the uniqueness of the data presented here. Nevertheless, considering that the frequency and magnitude of extreme precipitation events are likely to increase in the immediate future as a consequence of climate change (Hartmann et al., 2013; Huntington, 2006), Gloria might represent events that are to be more frequent in the coming decades. In this sense, the data presented here serve as a valuable reference for catchments in the study region and in other areas with similar climate and expected changes.

The data obtained from the sensors that were installed in the near-stream monitoring wells give a further idea of the hydrological magnitude of this massive storm. For example, the sensor located $2 \mathrm{~m}$ from the Font del Regàs stream channel indicated a persistent flooding of the riparian zone during ca. 1.5 days. According to our records, the water column above the soil surface reached up to nearly half a meter. Traces of floods such as accumulation of small quantities of sandy sediments and woody debris have been previously observed at this location, but never near the level observed during Gloria. Analogously, flooding of the soil at Fuirosos was recorded for a period of ca. 5.5 days with a peak of over $1.5 \mathrm{~m}$ of water above the soil surface. These large floods of near-stream areas associated with extreme precipitation events such as Gloria can have strong impacts on stream morphology, riverbank and riparian soil erosion, riparian biota, and microbial processes (Fisher et al., 1982; Friedman \& Lee, 2002; Ou et al., 2019; Tonkin et al., 2018).

Extreme precipitation events offer both an opportunity to improve our understanding of catchment hydrology and a challenge to be investigated, as they can be dangerous to study in situ and can damage technical equipment and monitoring installations. In this sense, the available stream water level data series at both catchments were constrained by logistical challenges, especially at Font del Regàs and specifically during Gloria, when some of our hydrological instrumentation was damaged or lost. However, given that stream water and near-stream groundwater led to consistent results and the same interpretation of the data within each individual catchment, we were able to investigate the overall hydrological response of the two catchments during the extreme Gloria event by using the available nearstream groundwater level time series, even after the loss of in-stream sensors. The time to reach the stage hydrograph peak and the duration of the hydrological response during Gloria were the longest or second longest of all recorded events for both catchments. This observation is not surprising given that these two descriptors are evidently related to the duration and accumulated precipitation of rainfall events. The time lapse between the beginning of Gloria and the beginning of the associated hydrological response was relatively long in both catchments, but this descriptor might relate to the rainfall event characteristics of the beginning of the event and Gloria was particularly light $\left(<0.5 \mathrm{~mm} \mathrm{~h}^{-1}\right)$ and accumulated little precipitation $(<3 \mathrm{~mm})$ during its initial $3 \mathrm{~h}$ at both sites. More importantly, the lag times that maximized the cross-correlation with the precipitation inputs at the two catchments were relatively similar during this moderately intense event (mean rainfall intensity at Font del Regàs and Fuirosos were $6.6 \mathrm{~mm} \mathrm{~h}^{-1}$ and $3.5 \mathrm{~mm} \mathrm{~h}^{-1}$, respectively). The lag time during Gloria coincided with the median for all events at Font del Regás ( 5 h), and was lower than the median across all events but coincided with the median for events with mean rainfall intensity higher than $1.6 \mathrm{~mm} \mathrm{~h}^{-1}$ at Fuirosos (7.5 h). These results support our conclusion that intense precipitation events such as Gloria can homogenize stream responses in catchments with otherwise contrasting hydrological regimes.

\section{6 | CONCLUSIONS}

The results presented here shed light on our understanding of how catchments with contrasting hydrological regimes (i.e., perennial vs. intermittent) driven by contrasting local climates (i.e., sub-humid vs. semi-arid) respond to precipitation inputs. Stream responses at the semi-arid Fuirosos were more delayed and more variable than at the sub-humid Font del Regàs during rainfall events of light intensity. Yet, stream responses were relatively similar between the two catchments 
during more intense events including the extratropical cyclone Gloria. This convergence in hydrological responses during intense rainfall events can be explained by rapid development of hydrological connectivity independently of antecedent soil moisture conditions, which is the likely driver of the observed differences during rainfall events of low intensity. Furthermore, these patterns support the idea that intermittent streams with erratic flow regimes and low catchment hydrological connectivity characteristic of arid and semi-arid climates can be less sensitive to climate-induced changes than perennial streams with persistent flow regimes and extensive catchment hydrological connectivity characteristic of more humid climates (Botter et al., 2013).

We have shown that monitoring of both stream water and nearstream groundwater levels can be used to evaluate stream responses to precipitation inputs, including extreme rainfall events. Despite that our data set is relatively short, it is also unique because it provides observational hydrological data under exceptional climatic conditions determined by the extratropical cyclone Gloria. A clear commitment to scientific progress through public investment is required for establishing and running long-term monitoring programmes that can more effectively capture such exceptional phenomena (Fölster et al., 2014). This step is fundamental for improving hydrological understanding and modelling and, potentially, for implementing more effective management strategies that can mitigate the ecological and socioeconomic impacts of extreme precipitation events on riverine systems and their contributing landscapes.

\section{ACKNOWLEDGEMENTS}

JLL was funded by the project RIPARIONS granted by the European Commission through a Marie Skłodowska Curie Individual Fellowship (H2020-MSCA-IF-2018-834363) and by the Spanish Government through a Juan de la Cierva grant (FJCl-2017-32111). AL was supported by the Catalan Government through a Beatriu de Pinós grant (BP-2018-00082). SB work was funded by the CANTERA project (RTI2018-094521-B-100) and a Ramon y Cajal fellowship (RYC2017-22643) from the Spanish Ministry of Science, Innovation, and Universities through the State Research Agency/European Regional Development Fund (AEI/FEDER-UE). We would like to thank Montserrat Soler for her support on maintaining the data set presented here, Eugènia Martí for her insights during an early version of the manuscript, the Regàs family for sharing their meteorological data, and Mireia Vila and Joaquim Serra for facilitating access to precipitation data from the Montnegre i el Corredor Park and the Maresme Regional Council.

\section{DATA AVAILABILITY STATEMENT}

Stream water and near-stream groundwater level data from the two monitoring sites Font del Regàs and Fuirosos presented in the study are stored in the research data repository Hydroshare at https:// www.hydroshare.org/resource/928632f2ebcb42c59a3c2e6e6d588bcc/ . This data set is published with an associated DOI, publicly available, citable, and accompanied by detailed metadata information. Precipitation and temperature data from the Servei Meteorologic de Catalunya
(SMC, Catalan Meteorological Service) presented in the study are publicly available at https://analisi.transparenciacatalunya.cat/MediAmbient/Dades-meteorol-giques-de-la-XEMA/nzvn-apee.

\section{ORCID}

José L. J. Ledesma (D) https://orcid.org/0000-0002-4181-5498

Anna Lupon (iD https://orcid.org/0000-0001-6655-8531

Susana Bernal DiD https://orcid.org/0000-0002-6726-8840

\section{REFERENCES}

Alexander, L. V., Zhang, X., Peterson, T. C., Caesar, J., Gleason, B., Tank, A. M. G., Haylock, M., Collins, D., Trewin, G., Rahimzadeh, F., Tagipour, A., Kumar, K., Revadekar, J., Griffiths, G., Vincent, L., Stephenson, D. B., Burn, J., Aguilar, E., Brunet, M., \& VázquezAguirre, J. L. (2006). Global observed changes in daily climate extremes of temperature and precipitation. Journal of Geophysical ResearchAtmospheres, 111, D05109. https://doi.org/10.1029/2005jd006290

Ali, G. A., \& Roy, A. G. (2010). Shopping for hydrologically representative connectivity metrics in a humid temperate forested catchment. Water Resources Research, 46, W12544. https://doi.org/10.1029/ 2010 wr009442

Amores, A., Marcos, M., Carrió, D. S., \& Gómez-Pujol, L. (2020). Coastal impacts of storm Gloria (January 2020) over the North-Western Mediterranean. Natural Hazards and Earth System Sciences, 20(7), 19551968. https://doi.org/10.5194/nhess-20-1955-2020

Àvila, A., Bonilla, D., Rodà, F., Piñol, J., \& Neal, C. (1995). Soilwater chemistry in a holm oak (Quercus ilex) forest: Inferences on biogeochemical processes for a montane-Mediterranean area. Journal of Hydrology, 166(1-2), 15-35. https://doi.org/10.1016/0022-1694(94) 02608-e

Àvila, A., Neal, C., \& Terradas, J. (1996). Climate change implications for streamflow and streamwater chemistry in a Mediterranean catchment. Journal of Hydrology, 177(1-2), 99-116. https://doi.org/10.1016/ 0022-1694(95)02789-0

Àvila, A., Piñol, J., Rodà, F., \& Neal, C. (1992). Storm solute behavior in a montane Mediterranean forested catchment. Journal of Hydrology, 140(1-4), 143-161. https://doi.org/10.1016/0022-1694 (92)90238-q

Azarnivand, A., Camporese, M., Alaghmand, S., \& Daly, E. (2020). Simulated response of an intermittent stream to rainfall frequency patterns. Hydrological Processes, 34(3), 615-632. https://doi.org/10.1002/hyp. 13610

Barker, L. J., Hannaford, J., Chiverton, A., \& Svensson, C. (2016). From meteorological to hydrological drought using standardised indicators. Hydrology and Earth System Sciences, 20(6), 2483-2505. https://doi. org/10.5194/hess-20-2483-2016

Bernal, S., Butturini, A., \& Sabater, F. (2002). Variability of DOC and nitrate responses to storms in a small Mediterranean forested catchment. Hydrology and Earth System Sciences, 6(6), 1031-1041. https://doi. org/10.5194/hess-6-1031-2002

Bernal, S., Butturini, A., \& Sabater, F. (2005). Seasonal variations of dissolved nitrogen and DOC: DON ratios in an intermittent Mediterranean stream. Biogeochemistry, 75(2), 351-372. https://doi.org/10. 1007/s10533-005-1246-7

Bernal, S., Lupon, A., Wollheim, W. M., Sabater, F., Poblador, S., \& Martí, E. (2019). Supply, demand, and in-stream retention of dissolved organic carbon and nitrate during storms in Mediterranean forested headwater streams. Frontiers in Environmental Science, 7, 60. https://doi.org/10. 3389/fenvs.2019.00060

Bernal, S., \& Sabater, F. (2008). The role of lithology, catchment size and the alluvial zone on the hydrogeochemistry of two intermittent Mediterranean streams. Hydrological Processes, 22(10), 1407-1418. https:// doi.org/10.1002/hyp.6693 
Bernal, S., von Schiller, D., Martí, E., \& Sabater, F. (2012). In-stream net uptake regulates inorganic nitrogen export from catchments under base flow conditions. Journal of Geophysical Research-Biogeosciences, 117, G00N05. https://doi.org/10.1029/2012jg001985

Blöschl, G., Bierkens, M. F. P., Chambel, A., Cudennec, C., Destouni, G., Fiori, A., Kirchner, J. W., McDonnell, J. J., Savenije, H. H. G., Sivapalan, M., Stumpp, C., Toth, E., Volpi, E., Carr, G., Lupton, C., Salinas, J., Széles, B., Viglione, A., Aksoy, H., \& Zhang, Y. (2019). Twenty-three unsolved problems in hydrology (UPH) - a community perspective. Hydrological Sciences Journal-Journal Des Sciences Hydrologiques, 64(10), 1141-1158. https://doi.org/10.1080/02626667. 2019.1620507

Botter, G., Basso, S., Rodriguez-Iturbe, I., \& Rinaldo, A. (2013). Resilience of river flow regimes. Proceedings of the National Academy of Sciences of the United States of America, 110(32), 12925-12930. https://doi. org/10.1073/pnas.1311920110

Bracken, L. J., Wainwright, J., Ali, G. A., Tetzlaff, D., Smith, M. W., Reaney, S. M., \& Roy, A. G. (2013). Concepts of hydrological connectivity: Research approaches, pathways and future agendas. EarthScience Reviews, 119, 17-34. https://doi.org/10.1016/j.earscirev. 2013.02.001

Brockwell, P. J., \& Davis, R. A. (1991). Time series: Theory and methods (2nd ed., pp. 373-375). Springer Verlag.

Butturini, A., Bernal, S., Nin, E., Hellin, C., Rivero, L., Sabater, S., \& Sabater, F. (2003). Influences of the stream groundwater hydrology on nitrate concentration in unsaturated riparian area bounded by an intermittent Mediterranean stream. Water Resources Research, 39, 1110. https://doi.org/10.1029/2001wr001260

Butturini, A., Bernal, S., Sabater, S., \& Sabater, F. (2002). The influence of riparian-hyporheic zone on the hydrological responses in an intermittent stream. Hydrology and Earth System Sciences, 6(3), 515-525. https://doi.org/10.5194/hess-6-515-2002

Doswell, C. A., Ramis, C., Romero, R., \& Alonso, S. (1998). A diagnostic study of three heavy precipitation episodes in the western Mediterranean region. Weather and Forecasting, 13(1), 102-124. https://doi.org/ 10.1175/1520-0434(1998)013<0102:adsoth>2.0.co;2

Fisher, S. G., Gray, L. J., Grimm, N. B., \& Busch, D. E. (1982). Temporal succession in a desert stream ecosystem following flash flooding. Ecological Monographs, 52(1), 93-110. https://doi.org/10.2307/2937346

Fölster, J., Johnson, R. K., Futter, M. N., \& Wilander, A. (2014). The Swedish monitoring of surface waters: 50 years of adaptive monitoring. Ambio, 43, 3-18. https://doi.org/10.1007/s13280-014-0558-z

Friedman, J. M., \& Lee, V. J. (2002). Extreme floods, channel change, and riparian forests along ephemeral streams. Ecological Monographs, 72(3), 409-425. https://doi.org/10.1890/0012-9615(2002)072[0409: efccar]2.0.co;2

Gallart, F., Llorens, P., Latron, J., \& Regüés, D. (2002). Hydrological processes and their seasonal controls in a small Mediterranean mountain catchment in the Pyrenees. Hydrology and Earth System Sciences, 6(3), 527-537. https://doi.org/10.5194/hess-6-527-2002

Gaume, E., Bain, V., Bernardara, P., Newinger, O., Barbuc, M., Bateman, A., Blaškovičová, L., Blöschl, G., Borga, M., Dumitrescu, A., Daliakopoulos, I., Garcia, J., Irimescu, A., Kohnova, S., Koutroulis, A., Marchi, L., Matreata, S., Medina, V., Preciso, E., , \& Viglione, A. (2009). A compilation of data on European flash floods. Journal of Hydrology, 367(1-2), 70-78. https://doi.org/10.1016/j.jhydrol.2008.12.028

Gomi, T., Sidle, R. C., Miyata, S., Kosugi, K., \& Onda, Y. (2008). Dynamic runoff connectivity of overland flow on steep forested hillslopes: Scale effects and runoff transfer. Water Resources Research, 44, W08411. https://doi.org/10.1029/2007wr005894

Hartmann, D. L., Klein Tank, A. M. G., Rusticucci, M., Alexander, L. V., Bronnimann, S., Charabi, Y., Dentener, F. J., Dlugokencky, E. J., Easterling, D. R., Kaplan, A., Soden, B. J., Thorne, P. W., Wild, M., \& Zhai, P. M. (2013). Observations: Atmosphere and surface. In T. F. Stocker, D. Qin, G.-K. Plattner, M. Tignor, S. K. Allen, J. Boschung, A.
Nauels, Y. Xia, V. Bex, \& P. M. Midgley (Eds.), Climate change 2013: The physical science basis. Contribution of working group I to the fifth assessment report of the intergovernmental panel on climate change. Cambridge University Press, Cambridge.

Helsel, D. R. \& Hirsch, R. M. (2002). Statistical methods in water resources (04-A3). Retrieved from Reston, VA: http://pubs.er.usgs.gov/ publication/twri04A3.

Huntington, T. G. (2006). Evidence for intensification of the global water cycle: Review and synthesis. Journal of Hydrology, 319(1-4), 83-95. https://doi.org/10.1016/j.jhydrol.2005.07.003

Jencso, K. G., McGlynn, B. L., Gooseff, M. N., Wondzell, S. M., Bencala, K. E., \& Marshall, L. A. (2009). Hydrologic connectivity between landscapes and streams: Transferring reach-and plot-scale understanding to the catchment scale. Water Resources Research, 45, W04428. https://doi.org/10.1029/2008wr007225

Kaushal, S. S., Gold, A. J., Bernal, S., \& Tank, J. L. (2018). Diverse water quality responses to extreme climate events: An introduction. Biogeochemistry, 141(3), 273-279. https://doi.org/10.1007/s10533-018-0527-x

Kunkel, K. E., Pielke, R. A., \& Changnon, S. A. (1999). Temporal fluctuations in weather and climate extremes that cause economic and human health impacts: A review. Bulletin of the American Meteorological Society, 80(6), 1077-1098. https://doi.org/10.1175/1520-0477(1999) $080<1077$ :tfiwac $>2.0 . c 0 ; 2$

Ledesma, J. L. J., Ruiz-Pérez, G., Lupon, A., Poblador, S., Futter, M. N., Sabater, F., \& Bernal, S. (2021). Future changes in the dominant source layer of riparian lateral water fluxes in a subhumid Mediterranean catchment. Journal of Hydrology. 595, 126014. https://doi.org/10. 1016/j.jhydrol.2021.126014

Lee, L. J. E., Lawrence, D. S. L., \& Price, M. (2006). Analysis of water-level response to rainfall and implications for recharge pathways in the chalk aquifer, SE England. Journal of Hydrology, 330(3-4), 604-620. https://doi.org/10.1016/j.jhydrol.2006.04.025

Llasat, M. C. (2001). An objective classification of rainfall events on the basis of their convective features: Application to rainfall intensity in the northeast of Spain. International Journal of Climatology, 21(11), 1385-1400. https://doi.org/10.1002/joc.692

Llasat, M. C., Llasat-Botija, M., Prat, M. A., Porcú, F., Price, C., Mugnai, A., Lagouvardos, K., Kotroni, V., Katsanos, D., Michaelides, S., Yair, Y., Savvidou, K., \& Nicolaides, K. (2010). High-impact floods and flash floods in Mediterranean countries: The FLASH preliminary database. Advances in Geosciences, 23, 47-55. https://doi.org/10.5194/adgeo23-47-2010

Llorens, P., \& Domingo, F. (2007). Rainfall partitioning by vegetation under Mediterranean conditions. A review of studies in Europe. Journal of Hydrology, 335(1-2), 37-54. https://doi.org/10.1016/j.jhydrol.2006. 10.032

Lupon, A., Bernal, S., Poblador, S., Martí, E., \& Sabater, F. (2016). The influence of riparian evapotranspiration on stream hydrology and nitrogen retention in a subhumid Mediterranean catchment. Hydrology and Earth System Sciences, 20(9), 3831-3842. https://doi.org/10.5194/ hess-20-3831-2016

Lupon, A., Ledesma, J. L. J., \& Bernal, S. (2018). Riparian evapotranspiration is essential to simulate streamflow dynamics and water budgets in a Mediterranean catchment. Hydrology and Earth System Sciences, 22(7), 4033-4045. https://doi.org/10.5194/hess-22-4033-2018

Lupon, A., Sabater, F., Miñarro, A., \& Bernal, S. (2016). Contribution of pulses of soil nitrogen mineralization and nitrification to soil nitrogen availability in three Mediterranean forests. European Journal of Soil Science, 67(3), 303-313. https://doi.org/10.1111/ejss.12344

Magand, C., Alves, M. H., Calleja, E., Datry, T., Dörflinger, G., England, J., Gallart, F., Gómez, R., Jorda-Capdevila, D., Martí, E., Munne, A., Pastor, V. A., Stubbington, R., Tziortzis, I., \& Von Schiller, D. (2020). Intermittent rivers and ephemeral streams: What water managers need to know. Technical report - Cost ACTION CA 15113. https:// doi.org/10.5281/zenodo.3888474 
Marchi, L., Borga, M., Preciso, E., \& Gaume, E. (2010). Characterisation of selected extreme flash floods in Europe and implications for flood risk management. Journal of Hydrology, 394(1-2), 118-133. https://doi. org/10.1016/j.jhydrol.2010.07.017

Martín-Vide, J. (2020). Precipitacions torrencials a Catalunya: el temporal Gloria i perspectives de futur. In M. Canals \& J. Miranda (Eds.), Sobre el temporal Gloria (19-23.01.20), els seus efectes sobre el país i el que se'n deriva. Report de Resposta Ràpida $\left(\mathrm{R}^{3}\right)$. Institut d'Estudis Catalans.

McMillan, S. K., Wilson, H. F., Tague, C. L., Hanes, D. M., Inamdar, S., Karwan, D. L., Loecke, T., Morrison, J., Murphy, S. F., \& Vidon, P. (2018). Before the storm: Antecedent conditions as regulators of hydrologic and biogeochemical response to extreme climate events. Biogeochemistry, 141(3), 487-501. https://doi.org/10.1007/s10533-018-0482-6

Medici, C., Butturini, A., Bernal, S., Vázquez, E., Sabater, F., Vélez, J. I., \& Francés, F. (2008). Modelling the non-linear hydrological behaviour of a small Mediterranean forested catchment. Hydrological Processes, 22(18), 3814-3828. https://doi.org/10.1002/hyp.6991

Morbidelli, R., García-Marín, A. P., Al Mamun, A., Atiqur, R. M., AyusoMuñoz, J. L., Bachir Taouti, M., Baranowski, P., Bellocchi, G., Sangüesa-Pool, C., Bennett, B., Oyunmunkh, B., Bonaccorso, B., Brocca, L., Caloiero, T., Caporali, E., Caracciolo, D., CasasCastillo, M. C., Catalini, C. G., Chettih, M., \& Saltalippi, C. (2020). The history of rainfall data time-resolution in a wide variety of geographical areas. Journal of Hydrology, 590, 125258. https://doi.org/10.1016/j. jhydrol.2020.125258

Musolff, A., Schmidt, C., Selle, B., \& Fleckenstein, J. H. (2015). Catchment controls on solute export. Advances in Water Resources, 86, 133-146. https://doi.org/10.1016/j.advwatres.2015.09.026

Ou, Y., Rousseau, A. N., Wang, L. X., Yan, B. X., Gumiere, T., \& Zhu, H. (2019). Identification of the alteration of riparian wetland on soil properties, enzyme activities and microbial communities following extreme flooding. Geoderma, 337, 825-833. https://doi.org/10.1016/j. geoderma.2018.10.032

Padilla, A., \& Pulido-Bosch, A. (1995). Study of hydrographs of karstic aquifers by means of correlation and cross-spectral analysis. Journal of Hydrology, 168(1-4), 73-89. https://doi.org/10.1016/0022-1694(94) 02648-u

Pilgrim, D. H., Chapman, T. G., \& Doran, D. G. (1988). Problems of rainfallrunoff modelling in arid and semiarid regions. Hydrological Sciences Journal-Journal Des Sciences Hydrologiques, 33(4), 379-400. https:// doi.org/10.1080/02626668809491261

Poblador, S., Lupon, A., Sabaté, S., \& Sabater, F. (2017). Soil water content drives spatiotemporal patterns of $\mathrm{CO} 2$ and $\mathrm{N} 2 \mathrm{O}$ emissions from a Mediterranean riparian forest soil. Biogeosciences, 14(18), 4195-4208. https://doi.org/10.5194/bg-14-4195-2017

Quinn, G. P., \& Keough, M. J. (2002). Experimental design and data analysis for biologists. Cambridge University Press.

R Core Team. (2012). R: A language and environment for statistical computing.
Rojas, R., Feyen, L., Dosio, A., \& Bavera, D. (2011). Improving pan-European hydrological simulation of extreme events through statistical bias correction of RCM-driven climate simulations. Hydrology and Earth System Sciences, 15(8), 2599-2620. https://doi.org/10. 5194/hess-15-2599-2011

SMC. (2020). Dades meteorològiques de la XEMA.

Tonkin, J. D., Merritt, D. M., Olden, J. D., Reynolds, L. V., \& Lytle, D. A. (2018). Flow regime alteration degrades ecological networks in riparian ecosystems. Nature Ecology \& Evolution, 2(1), 86-93. https://doi.org/ 10.1038/s41559-017-0379-0

Toreti, A., Xoplaki, E., Maraun, D., Kuglitsch, F. G., Wanner, H., \& Luterbacher, J. (2010). Characterisation of extreme winter precipitation in Mediterranean coastal sites and associated anomalous atmospheric circulation patterns. Natural Hazards and Earth System Sciences, 10(5), 1037-1050. https://doi.org/10.5194/nhess-10-1037-2010

Tromp-van Meerveld, H. J., \& McDonnell, J. J. (2006). Threshold relations in subsurface stormflow: 2. The fill and spill hypothesis. Water Resources Research, 42, W02411. https://doi.org/10.1029/ 2004wr003800

Vázquez, E., Acuña, V., Artigas, J., Bernal, S., Ejarque, E., Gaudes, A., Ylla, I., Martí, E., Mas-Martí, E., Guarch, A., Muñoz, I., Romaní, A., Sabater, S., Sabater, F., Von Schiller, D., \& Butturini, A. (2013). Fourteen years of hydro-biogeochemical monitoring in a Mediterranean catchment. Die Bodenkultur: Austrian Journal of Agricultural Research, 64(3-4), 13-20.

Zimmer, M. A., \& McGlynn, B. L. (2018). Lateral, vertical, and longitudinal source area connectivity drive runoff and carbon export across watershed scales. Water Resources Research, 54(3), 1576-1598. https://doi. org/10.1002/2017wr021718

Zuecco, G., Rinderer, M., Penna, D., Borga, M., \& van Meerveld, H. J. (2019). Quantification of subsurface hydrologic connectivity in four headwater catchments using graph theory. Science of the Total Environment, 646, 1265-1280. https://doi.org/10.1016/j.scitotenv.2018. 07.269

\section{SUPPORTING INFORMATION}

Additional supporting information may be found in the online version of the article at the publisher's website.

How to cite this article: Ledesma, J. L. J., Lupon, A., \& Bernal, S. (2021). Hydrological responses to rainfall events including the extratropical cyclone Gloria in two contrasting Mediterranean headwaters in Spain; the perennial font del Regàs and the intermittent Fuirosos. Hydrological Processes, 35(12), e14451. https://doi.org/10.1002/hyp.14451 